\title{
PENGARUH POLA TIDUR PEMAIN GAME ONLINE (GAMERS) TERHADAP GAMBARAN NILAI HEMATOKRIT
}

\author{
Hasnah ${ }^{1)}$, Nurul Ni'ma Azis ${ }^{1)}$, Abdul Azis ${ }^{1)}$. \\ ${ }^{1)}$ Teknologi Laboratorium Medis, Politeknik Kesehatan Muhammadiyah Makassar \\ Alamat Korespondensi: ha5nah.sarean@gmail.com
}

\section{Artikel info:}

Received: Desember 2021

Revised: Desember 2021

Accepted: Desember 2021

Publish: Desember 2021

Abstrak
Game online merupakan jenis permainan yang dimainkan dengan memanfaatkan jaringan internet untuk dapat terkoneksi satu sama lain dengan pemain lainnya baik melalui perangkat komputer maupun gadget. Game online dimainkan oleh para pemain game yang dikenal dengan istilah gamers. Gamers umumnya akan begadang untuk bermain game online yang memberi dampak buruk terhadap pola tidur. Sampel dalam penelitian ini adalah darah vena pemain game online yang memiliki pola tidur tidak teratur. Penelitian ini bertujuan untuk mengetahui gambaran nilai hematokrit terhadap pola tidur pada pemain game online. Penelitian ini dilakukan secara observasi laboratorium dengan menggunakan metode makrohematokrit. Jumlah sampel yang digunakan dalam penelitian ini adalah sebanyak 10 sampel. Hasil penelitian yang dilakukan terhadap 10 sampel diperoleh hasil yaitu 1 sampel mengalami penurunan nilai hematokrit (10\%) sementara 9 sampel lainnya diperoleh nilai hematokrit yang normal (90\%). Sehingga dapat disimpulkan bahwa pola tidur pada pemain game online beresiko mempengaruhi nilai hematokrit.

Kata Kunci: game online, hematokrit, pola tidur, makrohematokrit

\begin{abstract}
Online games are a type of game that is played by utilizing the internet network to be able to connect with each other with other players either through computers or gadgets. Online games are played by gamers known as Gamers. Gamers will generally stay up late to play online games that have a bad impact on sleep patterns. The sample in this study was the venous blood of online game players who had irregular sleep patterns. This study aims to determine the description of the hematocrit value on sleep patterns in online game players. This research was conducted by laboratory observation using the macrohematocrit method. The number of samples used in this study were 10 samples. The results of the research conducted on 10 samples showed that 1 sample experienced a decrease in the hematocrit value (10\%) while the other 9 samples obtained a normal hematocrit value (90\%). So, it can be concluded that sleep patterns in online game players are at risk of affecting the hematocrit value.

Keywords:online games, hematocrit, sleep patterns, macrohematocrit
\end{abstract}

\section{PENDAHULUAN}

Perkembangan dan kecanggihan yang dilahirkan oleh teknologi dalam peradaban manusia dari masa ke masa telah mengalami banyak peningkatan di semua aspek. Teknologi ada yang bersifat 
sederhana sampai yang kompleks dan memberikan banyak manfaat serta kemudahan dalam pekerjaan manusia.

Kecanggihan teknologi turut mempengaruhi pola dan gaya hidup manusia. Salah satu perkembangan teknologi yang sangat pesat adalah game online. Game online menjadi sarana hiburan paling tren di zaman ini. Pada mulanya game online ini banyak terdapat di pusat perkotaan seiring perkembangan kemudian merambah ke daerah-daerah.

Hal ini sejalan dengan banyaknya pemain yang memainkan game online ini sampai menjadi kecanduan bahkan game tidak lagi menjadi sekedar hiburan melainkan telah menjadi bagian dari kebutuhan. Penggunaan internet atau jasa online berupa game online telah berdampak negatif pada pola tidur dan kesejahteraan (Nigtyas, 2012).

Di Wilayah kabupaten Pangkep hampir semua jalan-jalan, cafe, resto dan tempat-tempat yang banyak menghadirkan komunitas bisa kita jumpai para pemain game online (gamers) yang bermain game online sampai larut malam sehingga membawa dampak buruk terhadap pola tidurnya.

Kebiasaan bermain game online dapat mengakibatkan pola tidur yang tidak teratur dan mengakibatkan pemain game begadang. Bahaya kesehatan yang bisa ditimbulkan dari begadang seperti anemia.

Jika seseorang terus menerus tidur terlalu malam, bisa jadi orang tersebut akan mengalami anemia. Hal ini disebabkan karena hormon dan produksi sel darah merah terganggu akibat metabolisme tubuh yang tidak seimbang pada saat proses metabolisme dan regenerasi sel berlangsung (Dewi, 2021).

Parameter pemeriksaan yang digunakan dalam penelitian ini adalah hematokrit. Pada hematokrit komponenkomponen darah menjadi terpisah dan terlihat menjadi tiga bagian yaitu bagian atas terdapat serum, bagian tengah terdapat buffy coat dan bagian yang paling bawah yaitu eritrosit (Nugraha, 2017).

Berdasarkan hasil penelitian yang dilakukan oleh Inshani et al., dari Program Studi Diploma 3 Analis Kesehatan STIKES Insan Cendekia Medika Jombang pada tahun 2020 dengan judul Gambaran Kadar Hemoglobin pada Remaja Gamer Pria diperoleh kesimpulan bahwa sebagian besar kadar hemoglobin pada remaja gamer pria mengalami penurunan. Jenis penelitian tersebut dilakukan dengan literature review.

Berdasarkan uraian di atas peneliti tertarik untuk melakukan penelitian terkait Gambaran Nilai Hematokrit Terhadap Pola Tidur pada Pemain Game Online (Gamers) di Wilayah Kecamatan Segeri Kabupaten Pangkep.

\section{METODE PENELITIAN}

\section{Alat dan Bahan}

Alat yang digunakan dalam penelitian ini yaitu tabung wintrobe, mikropipet, spuit $3 \mathrm{~mL}$, tourniquet, kapas alkohol, tisu, plaster, centrifuge dan tabung EDTA.

Bahan yang digunakan dalam penelitian ini yaitu darah vena.

\section{Prosedur Kerja}

\section{Pemilihan sampel}

Teknik pengambilan sampel dalam penelitian ini adalah purposive sampling, dengan kiteria durasi tidur hanya berkisar 1-4 jam, tidak mengkonsumsi suplemen penambah darah, tidak dalam keadaan haid untuk perempuan, usia berkisar 1525 tahun.

\section{Pengukuran hematokrit}

Disiapkan 1 buah tabung wintrobe yang bersih dan kering untuk satu sampel. Tabung diisi dengan darah vena EDTA sampai tanda garis lalu dimasukkan kedalam sentrifus diputar selama 30 menit dengan kecepatan $3000 \mathrm{rpm}$. Setelah disentrifus dilakukan penetapan. Penetapan nilai hematokrit dibaca dengan memperhatikan komponen dalam tabung mulai dari warna plasma, tebalnya lapisan yang tersusun atas leukosit dan trombosit 
(buffy coat) dan lapisan paling bawah yaitu lapisan eritrosit, kemudian dihitung volume eritrosit dan dinyatakan dalam persen (Nugraha dan Badrawi, 2018). Interpretasi hasil pada pria 40-54 \% dan wanita 36-46 \% (Nugraha dan Badrawi, 2018). Analisis data yang digunakan dalam penelitian ini yaitu analisis dalam bentuk tabel, dan dinarasikan secara deskriptif.

\section{HASIL DAN PEMBAHASAN}

Berdasarkan hasil penelitian tentang gambaran nilai hematokrit terhadap pola tidur pada pemain game online (gamers) di wilayah kecamatan Segeri kabupaten Pangkep yang dilaksanakan pada tanggal 3 Mei 2021 di Laboratorium Hematologi Politeknik Kesehatan Muhammadiyah Makassar diperoleh data sebagai berikut:

\section{Tabel 1. Penetapan Nilai Hematokrit} pada Pemain Game Online

\begin{tabular}{cccc}
\hline $\begin{array}{c}\text { Kode } \\
\text { Sampel }\end{array}$ & $\begin{array}{c}\text { Umur } \\
(\text { Tahun })\end{array}$ & $\begin{array}{c}\text { Hematokrit } \\
(\%)\end{array}$ & Keterangan \\
\hline A & 16 & $47 \%$ & Normal \\
B & 24 & $43 \%$ & Normal \\
C & 19 & $33 \%$ & Menurun \\
D & 17 & $43 \%$ & Normal \\
E & 15 & $47 \%$ & Normal \\
F & 19 & $42 \%$ & Normal \\
G & 23 & $48 \%$ & Normal \\
H & 15 & $42 \%$ & Normal \\
I & 19 & $46 \%$ & Normal \\
J & 17 & $40 \%$ & Normal \\
\hline
\end{tabular}

Dari tabel hasil penelitian penetapan nilai hematokrit pada pemain game online menggunakan 10 sampel.

Hematokrit merupakan volume eritrosit yang dimampatkan Packed Cell Volume (PCV) yaitu persentase volume eritrosit dalam darah yang dimampatkan dengan cara diputar pada kecepatan tertentu dan dalam waktu tertentu. Tujuan dilakukannya uji ini adalah untuk mengetahui konsentrasi eritrosit dalam darah.

Berdasarkan reprodusibilitas dan sederhananya, pemeriksaan ini paling dapat dipercaya untuk tes penyaring sederhana terhadap anemia, diantara pemeriksaan yang lainnya seperti kadar hemoglobin (Nugraha, 2020). Pada penelitian ini nilai hematokrit ditetapkan dengan menggunakan metode manual yaitu metode makrohematokrit.

Penelitian tentang Gambaran Nilai Hematokrit Terhadap Pola Tidur pada Pemain Game Online (Gamers) di Wilayah Kecamatan Segeri Kabupaten Pangkep menggunakan 10 sampel, dari 10 sampel yang diperiksa 1 diantaranya mengalami penurunan nilai hematokrit dan 9 sampel lainnya memperoleh nilai yang normal.

Sampel yang mengalami penurunan nilai hematokrit yaitu sampel $\mathrm{C}$ dengan nilai hematokrit $33 \%$ dan 9 sampel lainnya yaitu sampel A, B, D, E, F, G, H, I dan J berada pada kisaran nilai normal yaitu 40-54 \% pada pria dan 36$46 \%$ pada wanita. Hal ini bisa dipengaruhi oleh berbagai faktor selain dari pada pola tidur, seperti pola makan atau asupan yang masuk kedalam tubuh serta faktor usia.

Berdasarkan hasil observasi di lapangan durasi tidur pada sampel $\mathrm{C}$ terbilang kurang dari 6 jam yaitu rata-rata tidur per hari hanya 2 jam, dikarenakan durasi tidur pendek yang berpengaruh terhadap pola tidur, harusnya waktu tersebut dipakai untuk istirahat yang cukup. Dari segi pola makan sampel C juga tidak menerapkan pola makan yang sehat dan teratur. Hal ini yang kemungkinan berpengaruh terhadap penurunan nilai hematokrit.

Sementara pada sampel A, B, D, E, F, G, H, I dan J berdasarkan observasi di lapangan dari segi pola tidur tidak teratur, namun umumnya tetap memperhatikan pola makan yang berpotensi baik terhadap asupan nutrisi yang dibutuhkan oleh tubuh untuk menunjang prosesproses fisiologis yang terjadi dalam tubuh.

Menurut Angeline dalam Mayasari dan Sukeksi (2019), tidur sangat berperan penting dalam proses regenerasi sel dan pembentukan eritrosit yang biasanya 
terjadi pada malam hari. Sementara bagi kelompok masyarakat yang beraktivitas atau bekerja pada malam hari dengan durasi tidur yang kurang maka mengakibatkan proses metabolisme akan terganggu.

Proses regenerasi sel akan bekerja untuk memperbaiki jaringan ataupun sel yang rusak dan menggantinya dengan yang baru. Proses regenerasi sel dan pembentukan sel darah mulai terjadi ketika tubuh tidak melakukan aktivitas (istirahat). Pola tidur yang baik membantu untuk memaksimalkan proses regenerasi sel dan juga pembentukan eritrosit.

Sementara menurut Matayane (2014), asupan pun berperan penting dalam pembentukan eritrosit. Terganggunya produksi eritrosit bisa disebabkan oleh asupan yang dikonsumsi kurang mengandung nutrisi ataupun zat gizi yang terkandung di dalamnya tidak seimbang serta pola makan yang tidak teratur. Selain pola makan faktor yang dapat mempengaruhi nilai hematokrit adalah usia.

Sampel yang diteliti merupakan sampel dari usia muda, rata-rata nilai hematokrit berada pada kisaran normal. Menurut Suiraoka (2012), pada usia muda sistem fisiologi dan regenerasi sel seperti eritrosit masih bekerja dengan optimal, berbeda dengan orang di atas 30 tahun seiring berjalannya waktu sel akan mengalami penurunan fungsi akibat proses penuaan. Faktor-faktor tersebut dapat berpengaruh terhadap nilai hematokrit.

\section{KESIMPULAN DAN SARAN}

Berdasarkan hasil penelitian dengan persentase hasil yang diperoleh yaitu 1 sampel mengalami penurunan nilai hematokrit (10\%) dan 9 sampel lainnya memperoleh nilai hematokrit yang normal (90\%). Sehingga dapat disimpulkan bahwa pola tidur yang tidak teratur beresiko untuk mempengaruhi nilai hematokrit disamping faktor penyerta seperti pola makan dan asupan gizi serta faktor usia.

Disarankan untuk peneliti selanjutnya agar menggunakan metode yang lebih sensitif seperti hematology analyzer (Flowcytometri) dan jumlah sampel penelitian diperbanyak.

\section{DAFTAR PUSTAKA}

Dewi E, O, Puspita. (2021). Pengalaman Merubah Perilaku Begadang Untuk Menghindari Penyakit Anemia Kronis. Insitut Ilmu Kesehatan STRADA Indonesia.

Inshani, et. al. (2020). Gambaran Kadar Hemoglobin Pada Remaja Gamer Pria Program Studi Diploma 3 Analis Kesehatan STIKES Insan Cendekia Medika, Jombang.

Matayane et.all., (2014). Hubungan Antara Asupan Protein Dan Zat Besi Dengan Kadar Hemoglobin Mahasiswa Program Studi Pendidikan Dokter Angkatan 2013 Fakultas Kedokteran Universitas Sam Ratulangi. Jurnal e-Biomedik (eBM) 2 (3): 1.

Mayasari L. T., Sukeksi, A. (2019). Hubungan Jumlah Eritrosit Dengan Kadar Hemoglobin Pada Buruh Wanita Yang Bekerja Di Malam Hari. Universitas Muhammadiyah Semarang.

Nigtyas. (2012). Hubungan Antara Self Control Dengan Internet Addiction http://consultgerirn.org/uploads/Fil e/trythis/try_this_6_1.pdf. Diakses pada 1 April 2021.

Nugraha G., Badrawi,I. (2018). Pedoman Teknik Pemeriksaan Laboratorium Klinik. Penerbit Buku Mahasiswa Kesehatan. Jakarta.

Nugraha, G., (2017). Panduan Pemeriksaan Laboratorium Hematologi Dasar. Penerbit Buku Mahasiswa Kesehatan. Jakarta.

Nugraha, G., (2020). Packed Cell Volume $\quad(P C V)$. https://www.infolabmed.com/2020/ 12/packed-cell-volume-pcv.html. 
Diakses pada tanggal 25 April 2021.

Suiraoka, I. (2012). Penyakit Degeneratif. Medical Book, Yogyakarta. 